\title{
The Conversion of Abandoned Chestnut Forests to Managed Ones Does Not Affect the Soil Chemical Properties and Improves the Soil Microbial Biomass Activity
}

\author{
Mauro De Feudis ${ }^{1, * \mathbb{D}}$, Gloria Falsone ${ }^{1}$, Gilmo Vianello ${ }^{2}$ and Livia Vittori Antisari ${ }^{1}$ \\ 1 Department of Agricultural and Food Sciences, Alma Mater Studiorum-University of Bologna, Via Fanin, \\ 40, 40127 Bologna, Italy; gloria.falsone@unibo.it (G.F.); livia.vittori@unibo.it (L.V.A.) \\ 2 Centro Sperimentale per lo Studio e l'Analisi del Suolo (CSSAS), Alma Mater Studiorum-University of \\ Bologna, 40127 Bologna, Italy; gilmo.vianello@unibo.it \\ * Correspondence: mauro.defeudis2@unibo.it
}

Received: 20 June 2020; Accepted: 19 July 2020; Published: 22 July 2020

\begin{abstract}
Recently, several hectares of abandoned chestnut forests (ACF) were recovered into chestnut stands for nut or timber production; however, the effects of such practice on soil mineral horizon properties are unknown. This work aimed to (1) identify the better chestnut forest management to maintain or to improve the soil properties during the ACF recovery, and (2) give an insight into the effect of unmanaged to managed forest conversion on soil properties, taking in consideration sweet chestnut (Castanea sativa Mill.) forest ecosystems. The investigation was conducted in an experimental chestnut (Castanea sativa Mill.) forest located in the northern part of the Apennine chain (Italy). We identified an ACF, a chestnut forest for wood production (WCF), and chestnut forests for nut production with a tree density of 98 and 120 plants ha ${ }^{-1}\left(\mathrm{NCF}_{\mathrm{L}}\right.$ and $\mathrm{NCF}_{\mathrm{H}}$, respectively). $\mathrm{WCF}, \mathrm{NCF}_{\mathrm{L}}$ and $\mathrm{NCF}_{\mathrm{H}}$ stands are the result of the ACF recovery carried out in 2004. After 15 years since the ACF recovery, generally, the effects on the main soil chemical properties were negligible. Some differences occurred for the water-soluble organic carbon (WSOC) and microbial biomass and its activity. $\mathrm{NCF}_{\mathrm{L}}$ showed the highest WSOC content in the uppermost soil horizon likely due to higher amount of roots which are source of labile organic compounds. The higher WSOC amount might explain the greatest amount of microbial biomass in the A horizon of $\mathrm{NCF}_{\mathrm{L}}$. Furthermore, the microbial biomass harboring in the $\mathrm{A}$ horizon of $\mathrm{NCF}_{\mathrm{L}}$ has also shown both a better $\mathrm{C}$ use efficiency and a larger soil organic carbon immobilization in the microbial biomass itself. Our data would indicate that the ACF recovery into pure chestnut forests did not have negative impacts on soil chemical and biochemical properties, though chestnut stands for nut production with a low plant density are the most suitable ones.
\end{abstract}

Keywords: mountain soil; soil organic matter; soil microbial biomass; soil profiles; forest management

\section{Introduction}

In Europe, forest ecosystems cover more than one billion hectares [1]. Forests provide numerous services to humans such as the supply of fuel, raw materials and food, and play an important role for biodiversity protection, climate regulation, landscape preservation, etc. In this context, although the aboveground biomass is considered fundamental for life and landscape quality [2], soil plays a crucial role because, beyond to support the aboveground biomass functions, it preserves watersheds, hosts a wide variety of microorganisms and of meso- and macrofauna, regulates the biogeochemical cycling of nutrients, mitigate climate change, etc. [3]. Since soil is a key component of the forest 
ecosystems and soil properties are highly influenced by the forest management systems [4], several research papers focused on the evaluation of the influence of management on forest soils. For example, wood harvesting reduces the amounts of macro nutrients as $\mathrm{N}, \mathrm{P}, \mathrm{K}, \mathrm{Ca}$ and $\mathrm{Mg}$ [5] but it does not affect soil organic C [6,7]. Grüneberg et al. [8], in a study conducted in unmanaged and managed beech forests, found higher amount of soil labile organic C pool in the former than in the latter. Goldmann et al. [9], in a study carried out in managed and unmanaged beech forests and coniferous forests in southwest, central and northeast Germany, revealed the absence of differences in soil $\mathrm{pH}$ and C:N ratio. Wic Baena et al. [10], investigating maritime pine forest in central-eastern Spain, observed a higher amount of soil organic $C$ and soil microbial biomass in unmanaged forests than in those subjected to thinning. Borges et al. [11], in north eastern Portugal, found out a higher soil labile organic $\mathrm{C}$ content and organic $\mathrm{C}$ stock in non-tillage chestnut orchards than in those characterized by conventional tillage.

Another common management practice in forest ecosystems is the conversion of mixed forests to pure ones and vice versa which is driven by economic and ecological reasons [12,13]. The conversion from one type of forest vegetation to another can affect the soil properties [14]. For example, after 40 years from the conversion of a natural mixed forest to a pure forest in China, Yang et al. [15] found lower amounts of soil organic $C$, including the most labile ones, in pure forests than in native ones. Hizal et al. [16] reported that, after around 30 years from the conversion of a native broadleaf forest to a pure coniferous plantation, the native forest had a higher organic matter and total $\mathrm{N}$ contents and lower amounts of exchangeable potassium and calcium compared to planted stands. Similarly, the conversion of evergreen broad-leaved forests to plantations in the subtropical area of Eastern China decreased the soil $\mathrm{C}$ and $\mathrm{N}$ contents as well as soil $\mathrm{pH}$ [17]. Conversely, the study conducted by Haghdoost et al. [18] on the conversion of degraded natural forest to planted stands in Iran highlighted an increase in organic $\mathrm{C}$, total $\mathrm{N}$ and available $\mathrm{P}$ in the latter than in the former. Similar findings were observed in Northeast Brazil by da Silva et al. [19], who observed higher concentrations of soil organic matter and total $\mathrm{P}$ in regenerated than in native forests, while no differences occurred for soil microbial biomass and respiration.

Hence, the aforementioned literature would indicate how the human interventions in forest ecosystems have generally negative impacts on soil properties unless they have the aim of restoring degraded forests.

Sweet chestnut (Castanea sativa Mill.) forests represent an important landscape component in the European forest ecosystems covering an area of more than 2.5 million hectares [20]. Sweet chestnut cultivation has a long tradition in Europe; in fact, some evidence demonstrates chestnut tree spreading due to human activity since the IV century BC [21]. Sweet chestnuts' wide distribution all over Europe is mainly related to the multipurpose of the chestnut trees because they can be used for wood and food production and landscape conservation [22,23]. During the 20th century, many chestnut stands were abandoned due both to the spread of the Asian chestnut gall wasp and chestnut blight $[24,25]$ and to the rural depopulation [26]. Because of the abandonment, these chestnut stands are generally invaded by those tree species that persisted on such lands before chestnut tree spreading by humans [27-29] and progressively develop the features of natural woodland. However, in recent decades, thanks to the increased prices of the chestnut nuts [30] and the increasing interest both in eco-friendly wood biomass-derived products [31] and chestnut timbers in the structural sector [32], old chestnut stands are being restored.

Given the possible extension of chestnut stands in the European forest ecosystems [33] and the very few researches carried out on soil chestnut forests, the aim of the present work was to give an insight into the effects of conversion from unmanaged to managed chestnut forest on soil properties. Furthermore, the present study aimed also to identify the best chestnut forest management method to maintain or to improve the soil quality during the restoration of abandoned chestnut forests. We speculated that the recovery of abandoned chestnut forests reduces the concentrations of both soil organic matter and major nutrients and negatively affects the soil microbial biomass and its activity. 
Furthermore, we hypothesized that, among the managed chestnut forests, stands used for wood production purposes could affect the soil properties less negatively because of their higher tree density.

\section{Materials and Methods}

\subsection{Study Area and Soil Sampling}

The study area is the experimental chestnut forest located in Granaglione (Italy) in the northern part of the Apennine chain $\left(44^{\circ} 08^{\prime} \mathrm{N}, 10^{\circ} 57^{\prime} \mathrm{E}\right)$ at an altitude ranging from 650 to $750 \mathrm{~m}$ above sea level (Figure 1).

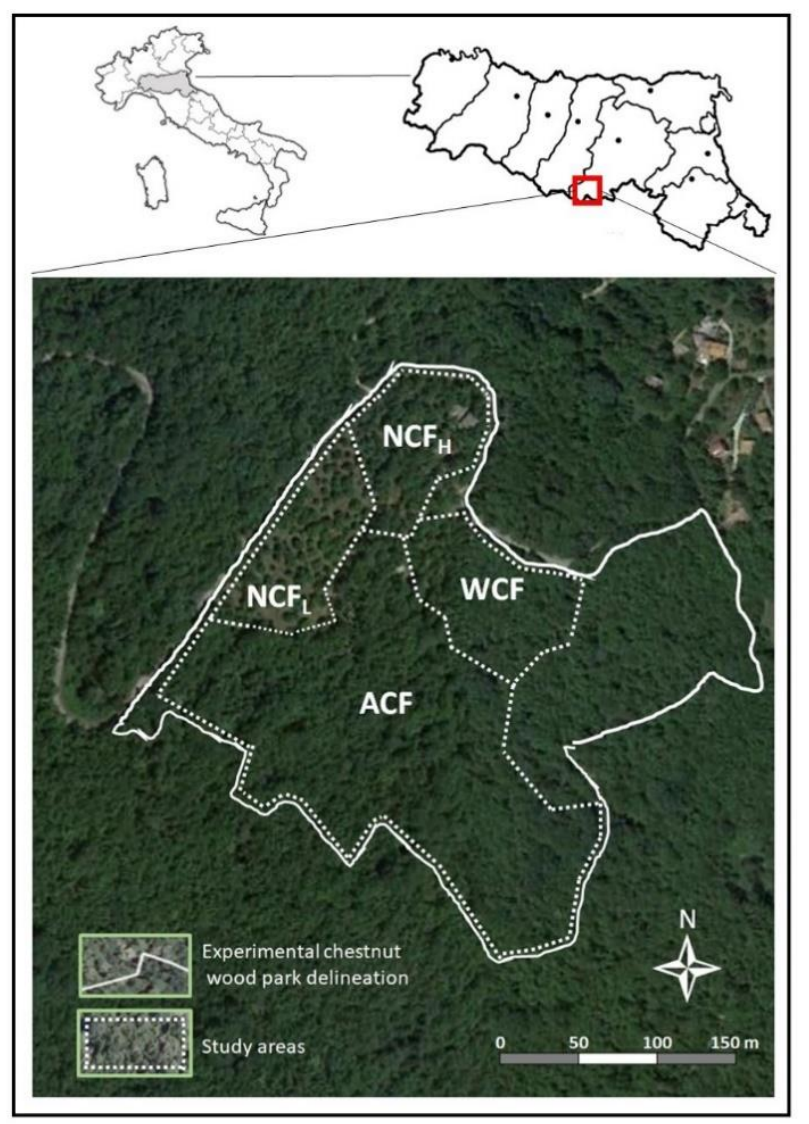

Figure 1. Location of study sites in the northern part of the Apennine chain, Italy. ACF: abandoned chestnut forest; chestnut forest for wood production (WCF); chestnut forest for nut production with a tree density of 98 plants ha ${ }^{-1}\left(\mathrm{NCF}_{\mathrm{L}}\right)$; a chestnut forest for nut production with a tree density of 120 plants ha ${ }^{-1}\left(\mathrm{NCF}_{\mathrm{H}}\right)$.

Owing to the cold, temperate climate, the rainfall in this area has an annual average of $905 \mathrm{~mm}$ with July as the driest month $(42 \mathrm{~mm})$ and November as the wettest one $(113 \mathrm{~mm})$. The mean annual air temperature is $12.2^{\circ} \mathrm{C}$ with July as the warmest month $\left(22.0^{\circ} \mathrm{C}\right)$ and January as the coldest one $\left(2.5^{\circ} \mathrm{C}\right)$. The parent material is sandstone, which belongs to the Miocene period, with feldspars, micas and quartz as the main minerals [34]. Within the study area, four study sites were identified: an abandoned chestnut forest with a tree density of about 370 plants ha $^{-1}$ (ACF), a chestnut forest for wood production with a tree density of 151 plants ha ${ }^{-1}$ (WCF), a chestnut forest for nut production with a tree density of 98 plants ha ${ }^{-1}\left(\mathrm{NCF}_{\mathrm{L}}\right)$ and a chestnut forest for nut production with a tree density of 120 plants ha $^{-1}$ $\left(\mathrm{NCF}_{\mathrm{H}}\right)$. The ACF study site is composed of uneven-aged chestnut trees (73\% of the total tree numbers), with ages up to 200 years, and Abies alba Mill., Populus alba L., Populus nigra L., Prunus avium L. and Quercus pubescens Will. WCF, $\mathrm{NCF}_{\mathrm{L}}$ and $\mathrm{NCF}_{\mathrm{H}}$ stands are the result of the recovery of abandoned chestnut forests carried out in 2004. Specifically, in $\mathrm{WCF}$ and $\mathrm{NCF}_{\mathrm{L}}$ the abandoned chestnut forests 
were clear-cut and the chestnut stumps of the clear-cut trees were grafted. In $\mathrm{NCF}_{\mathrm{H}}$ the recovery actions included the selection of the healthiest trees to maintain a tree spacing of about $10 \times 10 \mathrm{~m}$. Moreover, with the exception of ACF, in each study site, since 2016, the cut branches obtained by pruning together with organic residues accumulated on the soil surface are chopped yearly and left on the soil surface. The herb-layer vegetation of the selected stands covered less than $5 \%$ of the soil surface and it was composed of fern plants. All the study sites have a northwest exposition with a slope ranging from 12 to $18 \%$. The soils were classified as Leptic Skeletic Dystric Regosol (Loamic, Humic) according to the World Reference Base [35].

\subsection{Soil Sampling and Analysis}

Soil sampling was conducted in November 2019. In each study site, three soil pits, arranged according to the vertices of an equilateral triangle with sides $20 \mathrm{~m}$ long, were dug up to the BC horizon. Afterwards, for all pits, each identified soil mineral horizon was characterized according to Schoeneberger et al. [36] and sampled. The mean thickness of soil horizons is $3.75 \mathrm{~cm}$ for A horizon, $9 \mathrm{~cm}$ for $\mathrm{AB}, 12 \mathrm{~cm}$ for $\mathrm{Bw}$ and $12 \mathrm{~cm}$ for BC (Table 1). The soil colors of our soil profiles showed yellow-red hues, reflecting limited weathering, and the values increase from the $\mathrm{A}$ to $\mathrm{BC}$ horizons due to the reduction in the organic matter content. The A horizons had a weak developed granular structure, while the deeper horizons showed a blocky structure with aggregate dimensions less than $10 \mathrm{~mm}$. The fine earth content ranged from $86 \%$ in the A horizon of ACF to $55 \%$ in the BC of WCF with rock fragments increasing along the soil depth (Table 1). After soil collection, soil samples were air dried and passed through a 2-mm mesh to remove roots, visible plant debris, and stones. An aliquot of each soil sample was also finely ground.

Soil $\mathrm{pH}$ was measured at 1:2.5 soil-to-water ratio using a $\mathrm{pH}$ meter electrode. The particle size distribution was determined by pipette method [37]. The determination of total organic carbon (TOC) and total nitrogen (TN) concentrations was carried out by a CHN elemental analyzer (EA 1110 Thermo Fisher, Waltham, MA, USA) without pre-treatment with hydrochloric acid due to the absence of carbonates. The total amount of $\mathrm{Ca}, \mathrm{Mg}, \mathrm{Na}, \mathrm{K}, \mathrm{Fe}, \mathrm{Mn}, \mathrm{P}$ and $\mathrm{S}$ were measured using the inductively coupled plasma optical emission spectrometer (ICP-OES, Ametek, Spectro Arcos, Kleve, Germany) after aqua regia extraction [38]. Total organic P (TOP) was determined according to Kuo [39]. Specifically, for each sample $2 \mathrm{~g}$ of finely ground soil were ignited at $550{ }^{\circ} \mathrm{C}$ for $1 \mathrm{~h}$. After, the ignited soil samples and $2 \mathrm{~g}$ of non-ignited ones were extracted in $1 \mathrm{M} \mathrm{H}_{2} \mathrm{SO}_{4}$ (1:50 soil-to-solution ratio) for $16 \mathrm{~h}$. Phosphorus inside the extracts was determined by blue colorimetric method at $880 \mathrm{~nm}$ using a UV-visible spectrophotometer (V-530, Jasco, Hachioji, Tokyo, Japan). The TOP content was calculated by difference between the amount of $\mathrm{P}$ measured in ignited and non-ignited soil samples. The available $\mathrm{P}$ was extracted in $0.5 \mathrm{M} \mathrm{NaHCO}_{3}(\mathrm{pH}=8.5)$ and measured by the blue colorimetric method at $720 \mathrm{~nm}$ [40]. The cation exchange capacity (CEC) and the exchangeable cation contents were determined according to the method proposed by Orsini and Rèmy [41] and modified by Ciesielski and Sterckeman [42] using 0.017 M hexamminecobalt(III)chloride as extracting solution and the amounts of Co and exchangeable cations were measured by ICP-OES.

Microbial biomass $\mathrm{C}$ and $\mathrm{N}$ were estimated by the fumigation-extraction method using $0.5 \mathrm{M}$ $\mathrm{K}_{2} \mathrm{SO}_{4}$ as extracting solution [43,44]. Specifically, for each sample $10 \mathrm{~g}$ of 2-mm air dried soil was adjusted to $50 \%$ of field capacity and pre-incubated for 5 days. The soil samples were fumigated with $\mathrm{CHCl}_{3}$ for $24 \mathrm{~h}$ at $25^{\circ} \mathrm{C}$. After, the fumigated and non-fumigated samples were mixed with $40 \mathrm{~mL} 0.5 \mathrm{M}$ $\mathrm{K}_{2} \mathrm{SO}_{4}$ for $30 \mathrm{~min}$ on a horizontal shaker. The suspensions were filtered through $0.45 \mu \mathrm{m}$ membrane filter and $\mathrm{C}$ and $\mathrm{N}$ contents in the filtered solution were determined by a TOC-V CPN total organic carbon analyzer (Shimadzu, Kyoto, Japan). The microbial biomass $C$ was calculated as $\mathrm{EC} / \mathrm{k}_{\mathrm{EC}}$, where $\mathrm{EC}=$ (organic $\mathrm{C}$ extracted from fumigated soils) - (organic $\mathrm{C}$ extracted from non-fumigated soils) and $\mathrm{k}_{\mathrm{EC}}=0.45$. Microbial biomass $\mathrm{N}$ was calculated as $\mathrm{EN} / \mathrm{k}_{\mathrm{EN}}$, where $\mathrm{EN}=$ (total $\mathrm{N}$ extracted from fumigated soils) - (total $\mathrm{N}$ extracted from non-fumigated soils) and $\mathrm{k}_{\mathrm{EN}}=0.54$. 
Table 1. Morphological characteristics of representative soil profiles dug in an abandoned chestnut forest (ACF), a chestnut forest for wood production with a tree density of 151 plants ha ${ }^{-1}$ (WCF), a chestnut forest for nut production with a tree density of 120 plants ha ${ }^{-1}\left(\mathrm{NCF}_{\mathrm{H}}\right)$ and a chestnut forest for nut production with a tree density of 98 plants ha ${ }^{-1}\left(\mathrm{NCF}_{\mathrm{L}}\right)$.

\begin{tabular}{|c|c|c|c|c|c|c|c|c|c|c|}
\hline \multirow{2}{*}{ Forest } & \multirow{2}{*}{ Horizon } & \multirow{2}{*}{$\begin{array}{c}\text { Depth } \\
(\mathrm{cm})\end{array}$} & \multirow{2}{*}{$\begin{array}{c}\text { Boundary } \\
\mathrm{D} / \mathrm{T}\end{array}$} & \multicolumn{2}{|c|}{ Color (Munsell) } & \multirow{2}{*}{$\begin{array}{c}\text { Structure } \\
\mathrm{G} / \mathrm{S} / \mathrm{T}\end{array}$} & \multirow{2}{*}{$\begin{array}{c}\begin{array}{c}\text { Bulk } \\
\text { Density }\end{array} \\
\mathrm{g} / \mathrm{cm}^{3}\end{array}$} & \multirow{2}{*}{$\begin{array}{c}\text { Consistence } \\
\text { wp/ws }\end{array}$} & \multirow{2}{*}{$\begin{array}{c}\text { Roots } \\
\text { Q/S }\end{array}$} & \multirow{2}{*}{$\begin{array}{c}\begin{array}{c}\text { Rock } \\
\text { Fragments }\end{array} \\
\mathrm{S} / \mathrm{V} \% / \mathrm{R} \\
\end{array}$} \\
\hline & & & & dry & moist & & & & & \\
\hline \multirow{6}{*}{$\mathrm{ACF}$} & Oi & $2.5-0$ & $\mathrm{~A} / \mathrm{S}$ & & & & & & & \\
\hline & $\mathrm{Oe} / \mathrm{Oa}$ & $0-1.5$ & $\mathrm{~A} / \mathrm{S}$ & 10YR 3/2 & 10YR 2/2 & & & & & $\mathrm{fgr} / 1 \% / 2$ \\
\hline & A & $1.5-6$ & $\mathrm{~A} / \mathrm{W}$ & $10 Y R$ 5/3 & $10 Y R$ 4/3 & $1 / \mathrm{f} / \mathrm{gr}$ & 0.90 & po/so & $2 / \mathrm{f}-\mathrm{m}$ & $\mathrm{fgr} / 14 \% / 2$ \\
\hline & $\mathrm{AB}$ & $6-15$ & $\mathrm{C} / \mathrm{W}$ & 10YR 5/6 & 10YR 5/8 & $1 / \mathrm{f} / \mathrm{sbk}$ & 0.97 & $\mathrm{ps} / \mathrm{ss}$ & $2 / \mathrm{f}-\mathrm{m}$ & $\mathrm{fgr} / 20 \% / 2$ \\
\hline & Bw & $15-22$ & $\mathrm{~A} / \mathrm{W}$ & 10YR 6/4 & 10YR 5/8 & $1 / \mathrm{f} / \mathrm{sbk}$ & 0,96 & $\mathrm{p} / \mathrm{s}$ & $0 / \mathrm{m}$ & $\mathrm{fgr} / 21 \% / 2$ \\
\hline & $\mathrm{BC}$ & $22-30+$ & $\mathrm{U}$ & $10 Y R 6 / 4$ & $10 Y R$ 5/4 & $2 / \mathrm{f} / \mathrm{sbk}$ & 0.99 & $\mathrm{p} / \mathrm{s}$ & & $\operatorname{mgr} / 31 \% / 1$ \\
\hline \multirow{5}{*}{ WCF } & Oi & $2-0$ & $\mathrm{~A} / \mathrm{S}$ & & & & & & & \\
\hline & Oe/Oa & $0-0.7$ & $\mathrm{~A} / \mathrm{S}$ & $10 Y R 3 / 3$ & 10YR 3/1 & & & & $2 / v f-f$ & $\mathrm{fgr} / 3 \% / 2$ \\
\hline & A & $0.7-3$ & $\mathrm{~A} / \mathrm{W}$ & 10YR $4 / 3$ & 10YR 3/4 & $1 / f / g r$ & 0,79 & $\mathrm{ps} / \mathrm{ss}$ & $2 / \mathrm{f}$ & $\mathrm{fgr} / 20 \% / 2$ \\
\hline & $\mathrm{Bw}$ & $3-18$ & $\mathrm{C} / \mathrm{W}$ & 10YR 6/4 & 10YR 5/6 & $1 / \mathrm{f} / \mathrm{sbk}$ & 1.01 & $\mathrm{p} / \mathrm{s}$ & $1 / \mathrm{f}-\mathrm{m}$ & $\mathrm{mgr} / 32 \% / 1$ \\
\hline & $\mathrm{BC}$ & $18-30+$ & $\mathrm{U}$ & $10 Y R 6 / 6$ & 10YR 5/8 & $1 / \mathrm{f} / \mathrm{sbk}$ & 1.15 & $\mathrm{p} / \mathrm{s}$ & $0 / \mathrm{m}$ & $\operatorname{cgr} / 45 \% / 1$ \\
\hline \multirow{5}{*}{$\mathrm{NCF}_{\mathrm{H}}$} & Oi & $2-0$ & $\mathrm{~A} / \mathrm{S}$ & & & & & & & \\
\hline & Oe/Oa & $0-1.5$ & $\mathrm{~A} / \mathrm{S}$ & 10YR 3/3 & $10 \mathrm{YR} 3 / 2$ & & & & & $\mathrm{fgr} / 4 \% / 2$ \\
\hline & A & $1.5-6$ & $\mathrm{~A} / \mathrm{W}$ & 10YR $5 / 3$ & 10YR 3/4 & 1/f/gr & 1.01 & $\mathrm{ps} / \mathrm{so}$ & 2/f & $\mathrm{fgr} / 25 \% / 2$ \\
\hline & $\mathrm{Bw}$ & 6-20 & $\mathrm{C} / \mathrm{W}$ & 10YR $6 / 4$ & 10YR5/6 & $2 / \mathrm{f}-\mathrm{m} / \mathrm{sbk}$ & 1.15 & $\mathrm{p} / \mathrm{s}$ & $1 / \mathrm{f}-\mathrm{m}$ & $\mathrm{mgr} / 28 \% / 2$ \\
\hline & $\mathrm{BC}$ & $20-30+$ & $\mathrm{U}$ & 10YR 6/8 & 10YR 5/4 & $1 / \mathrm{f} / \mathrm{sbk}$ & 1.25 & $\mathrm{p} / \mathrm{s}$ & $0 / \mathrm{m}$ & $\mathrm{mgr} / 32 \% / 1$ \\
\hline \multirow{5}{*}{$\mathrm{NCF}_{\mathrm{L}}$} & Oi & $2.5-0$ & $\mathrm{~A} / \mathrm{S}$ & & & & & & & \\
\hline & Oe & $0-1$ & $\mathrm{~A} / \mathrm{S}$ & $10 \mathrm{YR} 4 / 2$ & $10 \mathrm{YR} 2 / 2$ & & & & $3 / v f$ & FGR/2\%/2 \\
\hline & $\mathrm{A}$ & $1-4$ & $\mathrm{C} / \mathrm{S}$ & $10 Y R$ 5/2 & 10YR 3/1 & $1 / \mathrm{f}-\mathrm{m} / \mathrm{gr}$ & 1.02 & $\mathrm{po} / \mathrm{so}$ & $3 / f$ & FGR $/ 16 \% / 2$ \\
\hline & $\mathrm{AB}$ & $4-13$ & $\mathrm{C} / \mathrm{W}$ & 10YR $6 / 3$ & 10YR $3 / 4$ & $2 / \mathrm{f}-\mathrm{m} / \mathrm{sbk}$ & 1.08 & ps/so & $1 / \mathrm{m}$ & MGR/30\%/1 \\
\hline & $\mathrm{BC}$ & $13-30$ & $\mathrm{U}$ & 10YR 6/4 & 10YR 4/6 & $2 / \mathrm{f}-\mathrm{m} / \mathrm{sbk}$ & 1.19 & ps/ss & $0 / \mathrm{f}-\mathrm{m}$ & MGR/36\%/1 \\
\hline
\end{tabular}

Horizon Boundary. (D) Distinctness: A = abrupt, $\mathrm{C}=$ clear-(T) Topography: $\mathrm{S}=$ smooth, $\mathrm{W}=$ wavy, $\mathrm{U}=$ unknown Structure. (G) Grade: $0=$ structureless, $1=$ weak, $2=$ moderate-(S) Size:

$\mathrm{f}=$ fine, $\mathrm{m}=$ medium $-(\mathrm{T})$ Type: $\mathrm{gr}=$ granular, abk $=$ angular blocky, sbk = subangular blocky. Consistence. $(\mathrm{P})$ Plasticity: $(\mathrm{w})$ po $=$ non plastic, $(\mathrm{w}) \mathrm{ps}=$ slightly plastic, $(\mathrm{w}) \mathrm{p}=$ moderately plastic-(S) Stickiness: (w) so = non sticky, (w) ss = slightly sticky, (w) s = moderately, (w) sv = very sticky Roots. (Q) Quantity: $0=$ very few, $1=$ few, $2=$ common, $3=$ many-(S) Size: $\mathrm{vf}=$ very fine, $\mathrm{f}=$ fine, $\mathrm{m}=$ medium. Rock fragments. $(\mathrm{S})$ Size: $\mathrm{fgr}=$ fine gravelly, $\mathrm{mgr}=$ medium gravelly; cgr $=$ coarse gravelly $-(\mathrm{V} \%)$ Fragment content $\%$ by volume $-(\mathrm{R})$ Roundness: $1=$ angular, 2 = subangular 
According to Chantigny et al. [45], $\mathrm{C}$ and $\mathrm{N}$ inside the filtered solution obtained from non-fumigated soil samples were considered as water-soluble organic C (WSOC) and water-soluble N (WSN).

Basal respiration was determined by quantifying the $\mathrm{CO}_{2}$ released in the process of microbial respiration during 28 days of incubation at $25{ }^{\circ} \mathrm{C}$ of incubation according to Vittori Antisari et al. [46] after conditioning of the samples at $50 \%$ of their field capacity and a pre-incubation of 5 days. In particular, $10 \mathrm{~g}$ of 2-mm air dried soil sample was placed in $0.5 \mathrm{~L}$ jars with hermetic lids and after 1-3-7-10-14-21-28 days the beginning of incubation, the amount of $\mathrm{CO}_{2}$ emitted from incubated soils was measured by alkali ( $1 \mathrm{M} \mathrm{NaOH}$ solution) absorption of the evolved $\mathrm{CO}_{2}$ and titration of the residual $\mathrm{OH}^{-}$with a standardized $\mathrm{HCl}$ solution. While the soil basal respiration (SBR) of each soil sample was computed as the average of the values measured during the incubation period, the cumulative amount of $\mathrm{CO}_{2}-\mathrm{C}$ (RCUM) was expressed as the total amount of $\mathrm{CO}_{2}$ evolved during the 28 days of incubation. Then the RCUM:Cmic, SBR:Cmic, RCUM:WSOC and Cmic:TOC ratios were also calculated.

\subsection{Statistical Analysis}

The statistical analyses were performed through $\mathrm{R}$ software 3.5.2. In order to monitor the effect of chestnut stand managements on the considered soil chemical and biological properties, for each pedogenic soil horizon one-way analysis of variance was performed. The normality and homogeneity of variances of residuals were tested by graphical analysis. If these assumptions were violated, the data were transformed according to the Box and Cox procedure. A comparison of the means was carried out using Tukey's HSD post-hoc test $(p<0.05)$.

\section{Results}

\subsection{Chemical Properties}

The soils under investigation had a silt-loam/loam texture and an acid $\mathrm{pH}$ without significant differences among the study sites (Table 2).

Table 2. Mean \pm standard error of sand, silt and clay contents, and $\mathrm{pH}$ of the soils under an abandoned chestnut forest $(\mathrm{ACF})$, a chestnut forest for wood production with a tree density of 151 plants ha $^{-1}$ (WCF), a chestnut forest for nut production with a tree density of 120 plants ha ${ }^{-1}\left(\mathrm{NCF}_{\mathrm{H}}\right)$ and a chestnut forest for nut production with a tree density of 98 plants ha ${ }^{-1}\left(\mathrm{NCF}_{\mathrm{L}}\right)$.

\begin{tabular}{cccccc}
\hline \multirow{2}{*}{ Horizon } & Forest & Sand & Silt & Clay & pH \\
\cline { 3 - 5 } & & \multicolumn{3}{c}{$\mathbf{g ~ k g}^{-\mathbf{1}}$} & \\
\hline \multirow{3}{*}{$\mathrm{A}$} & $\mathrm{ACF}$ & $429 \pm 8$ & $482 \pm 15$ & $89 \pm 24$ & $4.35 \pm 0.13$ \\
& $\mathrm{WCF}$ & $585 \pm 24$ & $356 \pm 12$ & $59 \pm 17$ & $4.15 \pm 0.13$ \\
& $\mathrm{NCF}_{\mathrm{H}}$ & $529 \pm 71$ & $416 \pm 58$ & $54 \pm 13$ & $4.41 \pm 0.26$ \\
& $\mathrm{NCF}_{\mathrm{L}}$ & $335 \pm 21$ & $537 \pm 20$ & $129 \pm 12$ & $4.48 \pm 0.12$ \\
\hline \multirow{2}{*}{$\mathrm{AB}$} & $\mathrm{ACF}$ & $387 \pm 64$ & $505 \pm 25$ & $108 \pm 39$ & $4.62 \pm 0.08$ \\
& $\mathrm{NCF}$ & $342 \pm 12$ & $515 \pm 14$ & $143 \pm 17$ & $4.75 \pm 0.08$ \\
\hline \multirow{3}{*}{$\mathrm{BW}$} & $\mathrm{ACF}$ & $357 \pm 37$ & $528 \pm 6$ & $115 \pm 32$ & $4.64 \pm 0.05$ \\
& $\mathrm{WCF}$ & $376 \pm 7$ & $503 \pm 13$ & $121 \pm 19$ & $4.69 \pm 0.05$ \\
& $\mathrm{NCF}$ & $425 \pm 64$ & $469 \pm 39$ & $107 \pm 29$ & $5.00 \pm 0.15$ \\
\hline \multirow{3}{*}{$\mathrm{BC}$} & $\mathrm{ACF}$ & $358 \pm 52$ & $526 \pm 32$ & $116 \pm 20$ & $4.75 \pm 0.13$ \\
& $\mathrm{WCF}$ & $368 \pm 36$ & $491 \pm 31$ & $141 \pm 13$ & $4.75 \pm 0.05$ \\
& $\mathrm{NCF}$ & $358 \pm 46$ & $498 \pm 11$ & $144 \pm 36$ & $4.99 \pm 0.14$ \\
& $\mathrm{NCF}$ & $325 \pm 10$ & $564 \pm 14$ & $111 \pm 8$ & $4.91 \pm 0.06$ \\
\hline
\end{tabular}

Taking in account the organic $\mathrm{C}$ and the most important soil nutrients ( $\mathrm{N}$ and $\mathrm{P}$ ), no differences in TOC, TN and TOP concentrations occurred among the forests (Figure 2a,b,e). For the most labile forms of these elements (i.e., available or soluble), both WSOC and WSN showed some differences in A 
horizon (Figure 2c,d), while the available P did not change among the stands (Figure 2f). In particular, $\mathrm{NCF}_{\mathrm{L}}$ showed the highest WSOC and WSN contents.

(a)

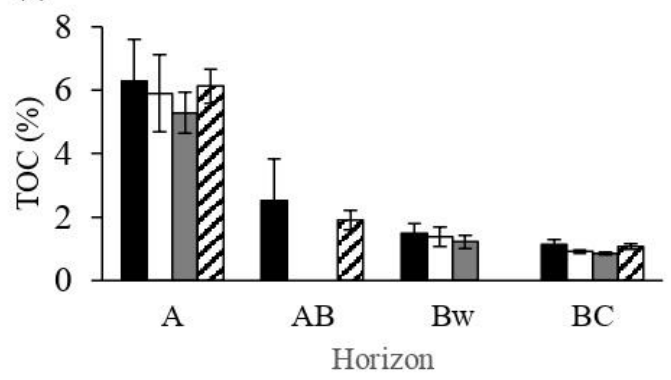

(c)

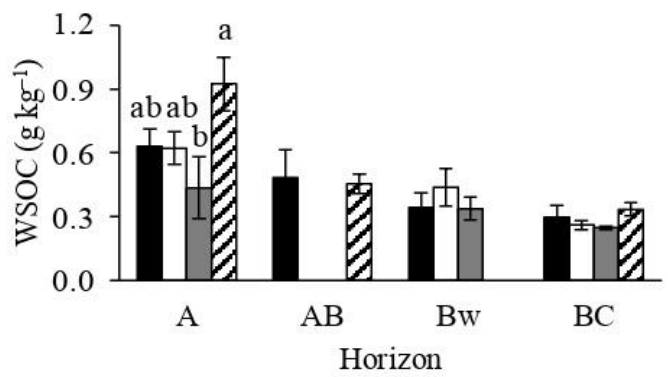

(e)

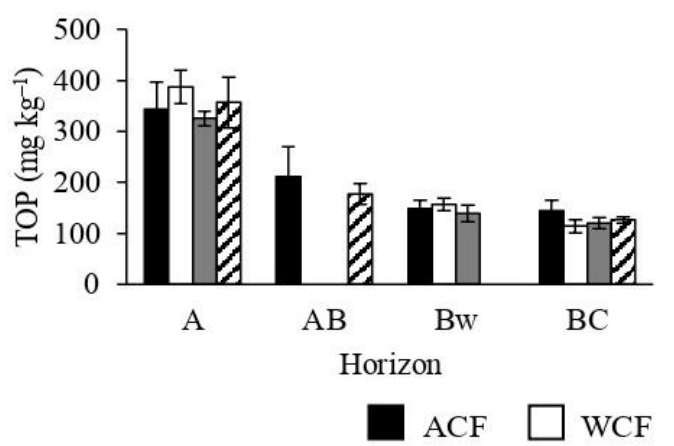

(b)

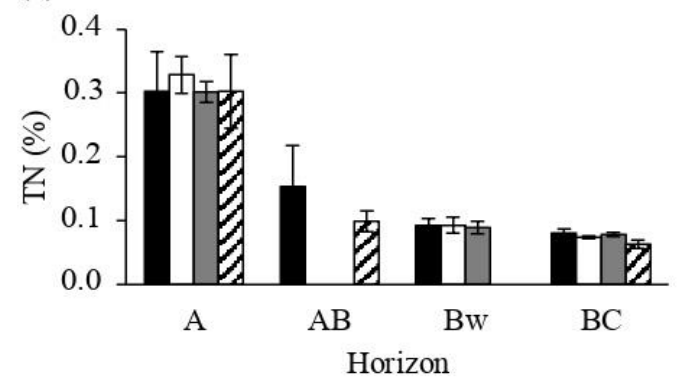

(d)

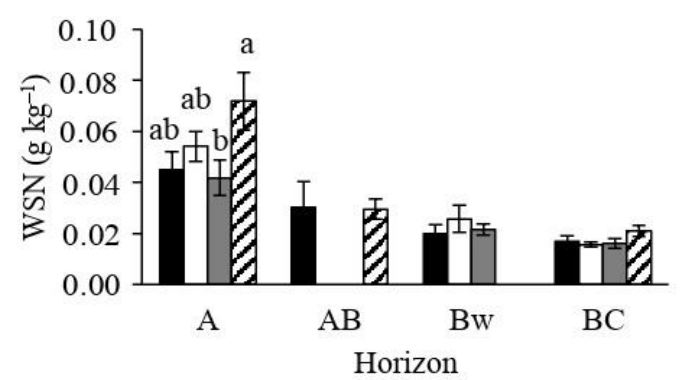

(f)

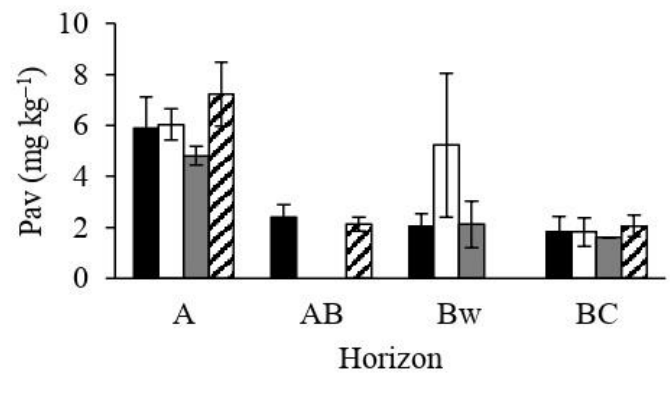

$\mathrm{NCF}_{\mathrm{H}} \quad \square \mathrm{NCF}_{\mathrm{L}}$

Figure 2. Concentrations of total organic carbon (TOC; a), total nitrogen (TN; b), water-soluble organic carbon (WSOC, c), water-soluble nitrogen (WSN; d), total organic phosphorus (TOP; e) and available $\mathrm{P}(\mathrm{Pav} ; \mathbf{f})$ of soils under an abandoned chestnut forest (ACF), a chestnut forest for wood production with a tree density of 151 plants ha ${ }^{-1}(\mathrm{WCF})$, a chestnut forest for nut production with a tree density of 120 plants ha ${ }^{-1}\left(\mathrm{NCF}_{\mathrm{H}}\right)$ and a chestnut forest for nut production with a tree density of 98 plants ha $^{-1}$ $\left(\mathrm{NCF}_{\mathrm{L}}\right)$. Error bars are the standard errors. Within each horizon, different letters indicate significant differences by Tukey's $t$-test $p \leq 0.05$.

As expected from the similar soil texture (Table 2) and TOC content (Figure 2a), the study sites showed similar $C E C$ values with exception of $A B$ horizon where ACF had a higher $C E C$ compared to $\mathrm{NCF}_{\mathrm{L}}$ (Figure 3a). The exchangeable Ca and Mg did not show differences among the stands (Figure $3 \mathrm{~b}, \mathrm{c}$ ) with exception of $\mathrm{B}$ horizon which showed the highest exchangeable $\mathrm{Mg}$ values in $\mathrm{ACF}$ and the lowest ones in WCF. With regard to exchangeable $\mathrm{K}, \mathrm{NCF}_{\mathrm{L}}$ displayed always the lowest values (Figure $3 \mathrm{~d}$ ). Furthermore, it is to notice that while in A horizon the highest exchangeable $\mathrm{K}$ values were observed in $\mathrm{ACF}$, in $\mathrm{B}$ horizon WCF showed lower exchangeable $\mathrm{K}$ values compared to $\mathrm{ACF}$ and $\mathrm{NCF}_{\mathrm{H}}$. For the exchangeable $\mathrm{Na}$, some differences occurred in $\mathrm{A}$ and $\mathrm{B}$ horizons (Figure 3e). Specifically, while in $\mathrm{A}$ horizon $\mathrm{NCF}_{\mathrm{L}}$ had higher exchangeable Na content compared to $\mathrm{WCF}$, in $\mathrm{B}$ horizon $\mathrm{NCF}_{\mathrm{H}}$ showed lower exchangeable Na values compared to WCF and ACF. Because of the few differences found for 
exchangeable bases and the similar CEC values, negligible are the differences found for the percentage base saturation (Figure $3 \mathrm{f}$ ) with exception of $\mathrm{B}$ horizon where a lower $\mathrm{BS}$ was observed in $\mathrm{NCF}_{\mathrm{H}}$ than in ACF.

(a)

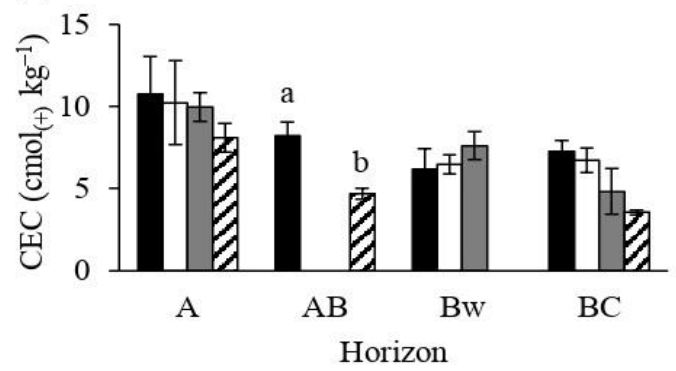

(c)

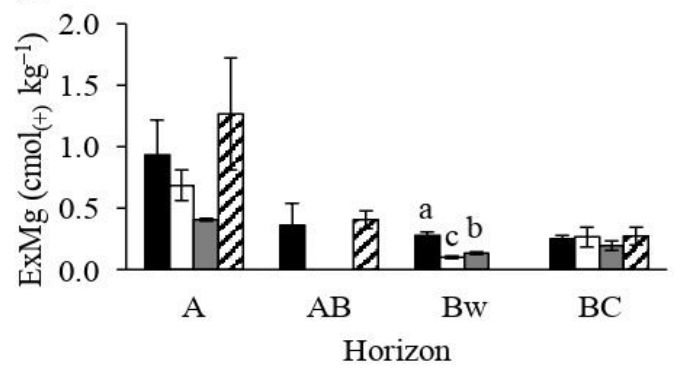

(e)

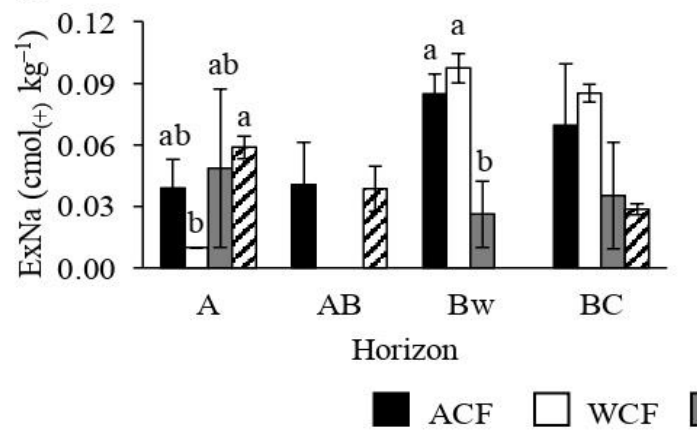

(b)

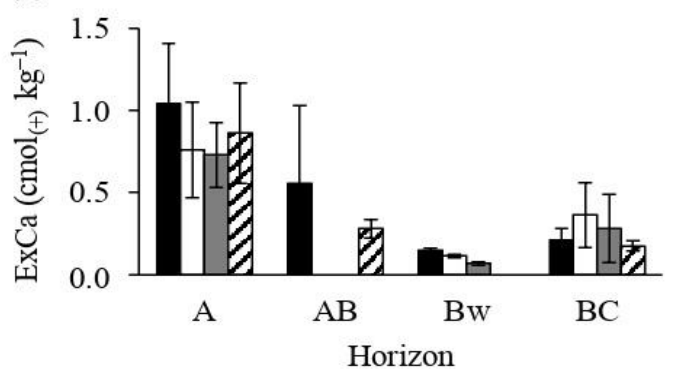

(d)

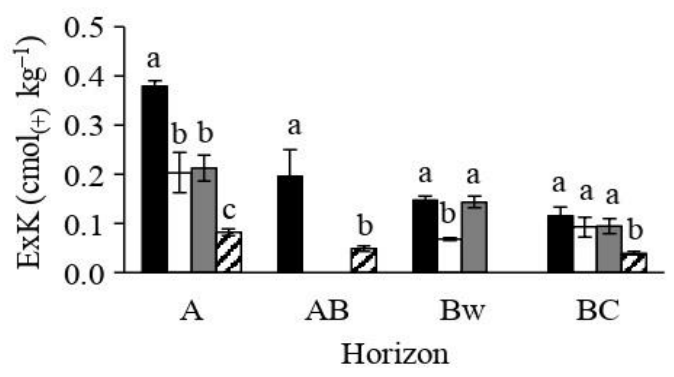

(f)

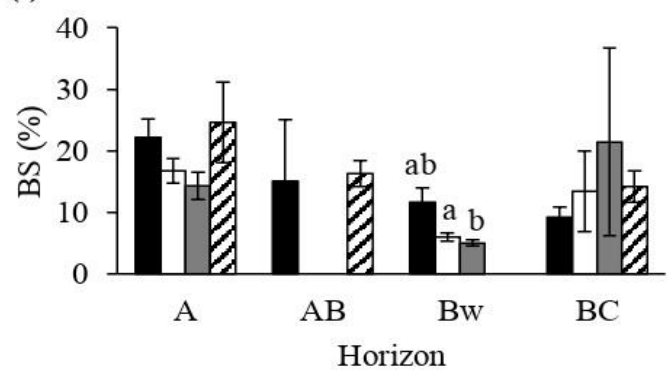

$\mathrm{NCF}_{\mathrm{H}} \square \mathrm{NCF}_{\mathrm{L}}$

Figure 3. Cation exchange capacity (CEC; a), concentrations of exchangeable calcium (ExCa; b), exchangeable magnesium (ExMg; c), exchangeable potassium (ExK; d), exchangeable sodium (ExNa; $\mathbf{e}$ ) and base saturation (BS; f) of soils under an abandoned chestnut forest (ACF), a chestnut forest for wood production with a tree density of 151 plants ha $^{-1}$ (WCF), a chestnut forest for nut production with a tree density of 120 plants ha ${ }^{-1}\left(\mathrm{NCF}_{\mathrm{H}}\right)$ and a chestnut forest for nut production with a tree density of 98 plants ha ${ }^{-1}\left(\mathrm{NCF}_{\mathrm{L}}\right)$. Error bars are the standard errors. Within each horizon, different letters indicate significant differences by Tukey's $t$-test $p \leq 0.05$.

Given the similar parent material of the soils, the differences are limited for the total element concentrations (Figure 4a-f). Generally, ACF exhibited the highest total $\mathrm{Ca}, \mathrm{Mg}$ and $\mathrm{K}$ contents (Figure $4 \mathrm{a}-\mathrm{c}$ ). Furthermore, in BC horizon WCF displayed the lowest total $\mathrm{K}$ content among the study sites. For the total amounts of $\mathrm{Na}$ and $\mathrm{P}$ (Figure $4 \mathrm{~d}, \mathrm{e}$ ), generally $\mathrm{NCF}_{\mathrm{L}}$ showed the highest values along the whole soil profile among the forests. Finally, a lack of differences was found the total $\mathrm{S}$ content. 
(a)

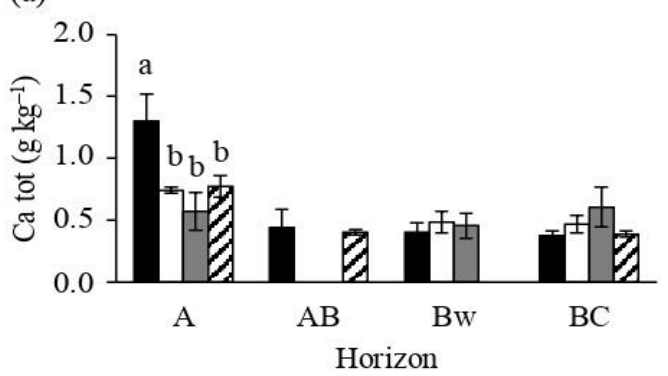

(c)

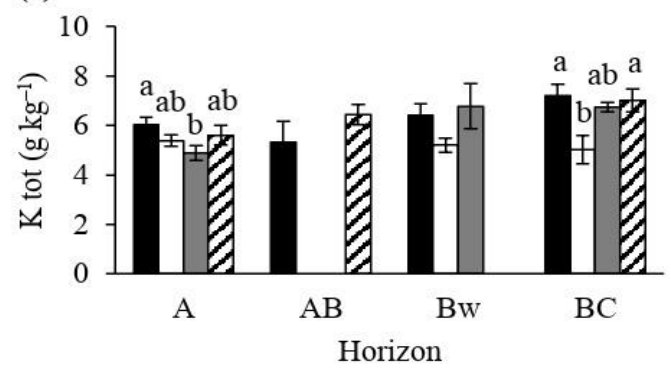

(e)

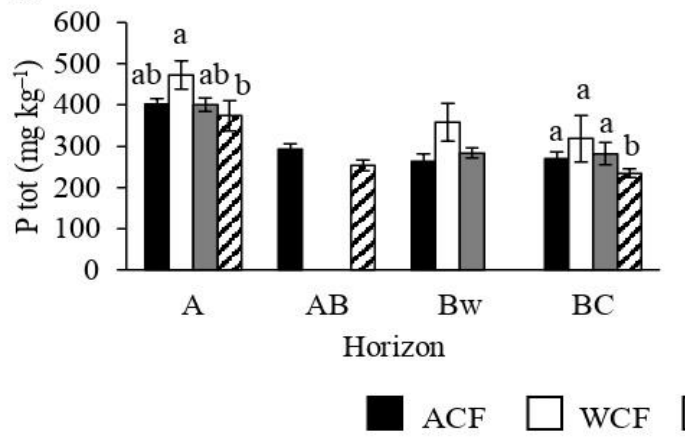

(b)

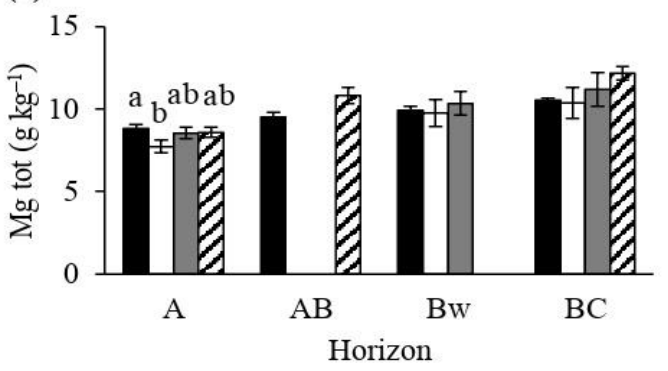

(d)

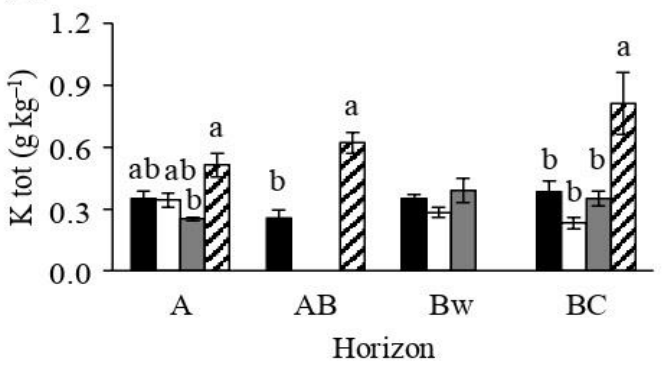

(f)

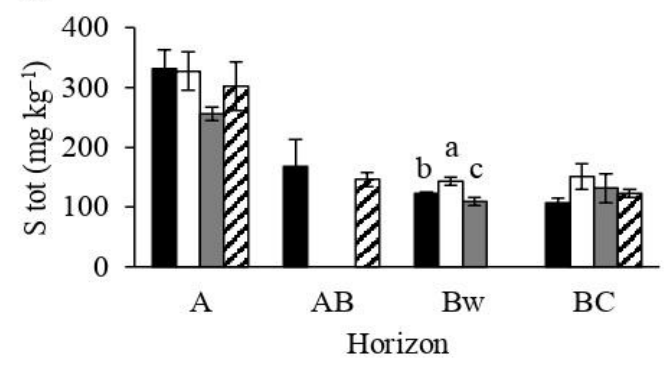

$\mathrm{NCF}_{\mathrm{H}} \bigotimes \mathrm{NCF}_{\mathrm{L}}$

Figure 4. Concentrations of total calcium (Ca tot; a), magnesium ( $\mathrm{Mg}$ tot; b), potassium ( $\mathrm{K}$ tot; $\mathbf{c}$ ), sodium (Na tot; $\mathbf{d}$ ), phosphorus (P tot; e) and sulfur ( $\mathrm{S}$ tot; $\mathbf{f}$ ) of soils under an abandoned chestnut forest $(\mathrm{ACF})$, a chestnut forest for wood production with a tree density of 151 plants ha ${ }^{-1}$ (WCF), a chestnut forest for nut production with a tree density of 120 plants ha ${ }^{-1}\left(\mathrm{NCF}_{\mathrm{H}}\right)$ and a chestnut forest for nut production with a tree density of 98 plants ha ${ }^{-1}\left(\mathrm{NCF}_{\mathrm{L}}\right)$. Error bars are the standard errors. Within each horizon, different letters indicate significant differences by Tukey's $t$-test $p \leq 0.05$.

\subsection{Biochemical Properties}

In A horizon, the highest microbial biomass $\mathrm{C}$ and $\mathrm{N}$ (Figure $5 \mathrm{a}, \mathrm{b}$ ) were found in $\mathrm{NCF}_{\mathrm{L}}$, while for the $\mathrm{BC}$ horizon the lowest microbial biomass $\mathrm{C}$ was observed in $\mathrm{NCF}_{\mathrm{H}}$. For the soil microbial respiration, some differences occurred only in BC horizon (Figure 5c,d). Specifically, the highest values of total amount of $\mathrm{CO}_{2}-\mathrm{C}$ and basal respiration were found in $\mathrm{NCF}_{\mathrm{L}}$, while the lowest ones in WCF.

Data of RCUM:Cmic and SBR:Cmic ratios (Figure $6 \mathrm{a}, \mathrm{b}$ ) for the A horizon displayed the lowest values in $\mathrm{NCF}_{\mathrm{L}}$. However, for the deepest soil horizons, $\mathrm{NCF}_{\mathrm{L}}$ and $\mathrm{NCF}_{\mathrm{H}}$ had the highest RCUM:Cmic and SBR:Cmic ratios. Regarding to RCUM:WSOC ratio, in A horizon, the lowest values were found in $\mathrm{NCF}_{\mathrm{L}}$, while in $\mathrm{B}$ horizon the highest RCUM:WSOC ratio was found in $\mathrm{NCF}_{\mathrm{H}}$. In $\mathrm{BC}$ horizon, instead, the highest RCUM:WSOC ratio was observed in $\mathrm{NCF}_{\mathrm{L}}$, whereas the lowest one in WCF. For the $\mathrm{Cmic}$ TOC ratio, in A horizon $\mathrm{NCF}_{\mathrm{L}}$ showed the highest value among the study sites, while in $\mathrm{B}$ horizon the Cmic:TOC ratio followed the following trend $\mathrm{WCF} \leq \mathrm{ACF} \leq \mathrm{NCF}_{\mathrm{H}}$. 

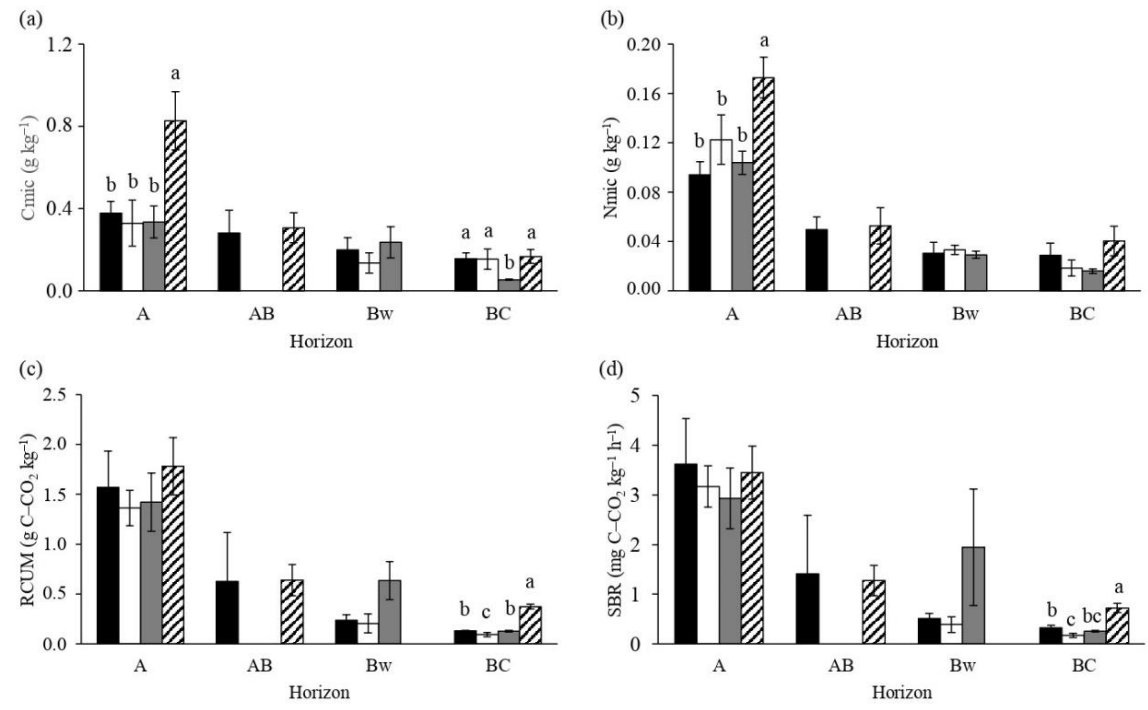

Figure 5. Concentrations of microbial biomass carbon (Cmic; a), microbial biomass nitrogen (Nmic; b), cumulative amount of $\mathrm{CO}_{2}-\mathrm{C}$ evolved during 21-days incubation experiment (RCUM; c) and soil basal respiration (SBR; d) of soils under an abandoned chestnut forest (ACF), a chestnut forest for wood production with a tree density of 151 plants ha ${ }^{-1}$ (WCF), a chestnut forest for nut production with a tree density of 120 plants ha ${ }^{-1}\left(\mathrm{NCF}_{\mathrm{H}}\right)$ and a chestnut forest for nut production with a tree density of 98 plants ha ${ }^{-1}\left(\mathrm{NCF}_{\mathrm{L}}\right)$. Error bars are the standard errors. Within each horizon, different letters indicate significant differences by Tukey's $t$-test $p \leq 0.05$.
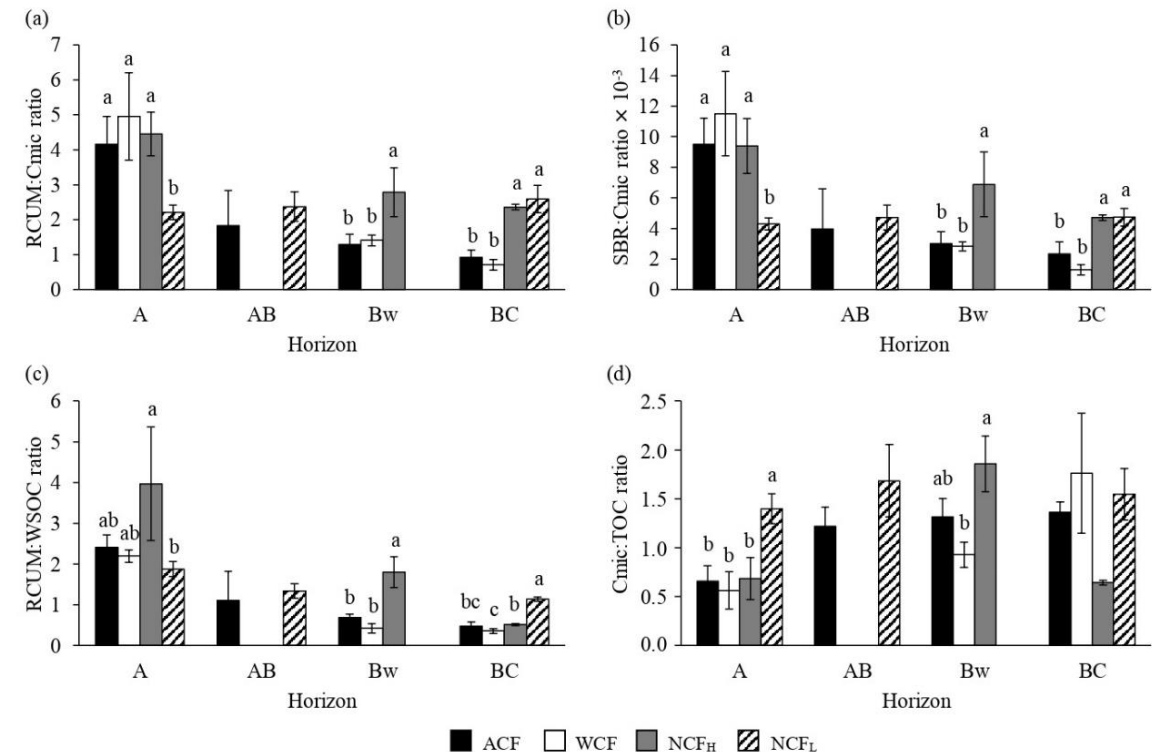

Figure 6. RCUM:Cmic (a), SBR:Cmic (b), RCUM:WSOC (c) and Cmic:TOC (d) ratios of soils under an abandoned chestnut forest (ACF), a chestnut forest for wood production with a tree density of 151 plants ha ${ }^{-1}$ (WCF), a chestnut forest for nut production with a tree density of 120 plants ha $^{-1}$ $\left(\mathrm{NCF}_{\mathrm{H}}\right)$ and a chestnut forest for nut production with a tree density of 98 plants ha ${ }^{-1}\left(\mathrm{NCF}_{\mathrm{L}}\right)$. Error bars are the standard errors. Within each horizon, different letters indicate significant differences by Tukey's $t$-test $p \leq 0.05$. RCUM = cumulative amount of $\mathrm{CO}_{2}-\mathrm{C}$ evolved during 21-days incubation experiment; $\mathrm{SBR}=$ soil basal respiration; $\mathrm{WSOC}=$ water-soluble organic carbon content; $\mathrm{TOC}=$ total organic carbon content. 


\section{Discussion}

Our research provides a unique opportunity to evaluate the effect of the conversion of an abandoned European chestnut forest to pure chestnut forests with different managements on some soil chemical and biochemical properties. In fact, it is rare to perform a field study with very similar pedo-climatic conditions that allows us to reduce the interference of uncontrolled factors.

The present study displayed how the major differences concerned the biochemical properties. Our findings are in accordance with previous studies, which reported a higher sensibility of soil biological properties compared to the chemical ones to the management practices both in agricultural [47-49] and forest ecosystems [10,50,51].

Taking in account the soil chemical properties, the similar concentrations of organic $\mathrm{C}$ among the study sites would suggest how the recovery of the abandoned chestnut forests into pure chestnut stands does not affect the most important indicator of soil quality [52]. Although WCF and ACF study sites have a greater tree density and, as a consequence, a larger aboveground biomass compared to $\mathrm{NCF}_{\mathrm{L}}$ and $\mathrm{NCF}_{\mathrm{H}}$ all the study sites showed similar values of organic $\mathrm{C}$. The results are in accordance with previous forestry studies $[53,54]$ which detected unaltered soil OC amounts among forests characterized by a different tree density and tree biomass. The lack of differences in OC could be assigned to the generally similar tree composition (100\% chestnut trees in $\mathrm{WCF}, \mathrm{NCF}_{\mathrm{H}}$ and $\mathrm{NCF}_{\mathrm{L}}$ and $73 \%$ in $\mathrm{ACF}$ ). Indeed, the vegetation types play a pivotal role in the control of the soil organic $C[55,56]$ because of the different litter quality which is species-specific [57]. Another possible reason for the similar OC values among the study sites can be attributed to the high amounts of sand (always higher than 33\%) and the low clay content (always lower than 15\%), which does not allow OC accumulation in our investigated soils [58,59]. Specifically, the predominance of a coarser soil texture implies a limited formation of organo-mineral complexes and, therefore, prevents physical protection against a microbial attack [60].

Despite the generally similar CEC values among the study sites, $\mathrm{NCF}_{\mathrm{L}}$ showed the lowest exchangeable $\mathrm{K}$ content for all soil horizons. The low exchangeable $\mathrm{K}$ values in $\mathrm{NCF}_{\mathrm{L}}$ can be assigned to the low amount of the element in the litter floor (Table S1 of Supplementary Materials). In fact, this is recognized in the litter floor nutrient recycling in the underlying mineral horizons [61-63]. Conversely, the rationale of the low amount of $\mathrm{K}$ in the litter floor is unclear because of the absence of data about the plant tissues.

Despite the similar parent material, and in no one of the study sites fertilizers are applied as well as no removal of plant residues is performed, the total amount of Ca showed the highest values in ACF. The different concentration of total Ca between ACF and the pure chestnut forests could be attributed to the Ca loss that likely occurred at the time of clear-cut practices due to the occurrence of soil erosion processes. Although we do not have data related to the possible occurrence of soil erosion, in literature it is recognized that clear-cut practices in mountainous forest areas cause the acceleration of the soil erosion processes [64] with consequent loss of nutrients accumulated in the eroded soil [65]. However, our hypothesis about the occurrence of soil erosion processes might be confirmed by the study conducted in our same experimental field by Vittori Antisari et al. [34] which found the loss of the surface soil mineral material after the clear-cut practices. The higher total Ca content in ACF than in pure chestnut forests can be also attributed to the scarce or lack of a forest canopy after clear-cut practices, which prevented the formation of the litter floor and, therefore, the soil Ca restoration through the organic material degradation and incorporation in the mineral soil. In fact, the pivotal role of the forest floor on soil nutrient cycles is well known [66]. However, this process was not observed for $\mathrm{Mg}, \mathrm{K}, \mathrm{Na}$ and $\mathrm{P}$, likely due to their much lower concentrations in the Oi horizon compared to $\mathrm{Ca}$. With regard to soil erosion, noteworthily, although the erosion processes are known to cause the loss of organic matter from the soils [67], in our case, the lack of differences in TOC content among the study sites would indicate rather efficient chestnut forest ecosystems in relation to the recovery of soil organic matter.

Although the study sites had a similar amount of TOC, which is considered an important source of labile organic $C$ [68], in the uppermost soil mineral horizon, $\mathrm{NCF}_{\mathrm{L}}$ showed the highest WSOC 
content. This high value can be assigned to the lower tree density. Specifically, since chestnut trees are sensitive to the competition with other trees [69,70], the high spacing among the plants could promoted plant growth [71,72] and, therefore, root development. However, we cannot exclude that the low plant density could have also promoted a wider distribution of the root system [73]. In fact, as reported in Table 1, in A horizon of $\mathrm{NCF}_{\mathrm{L}}$ we found a greater number of fine roots compared to the other study sites. In both cases, the larger root system could have promoted the increased presence of water-soluble organic compounds provided through the rhizodeposition processes $[74,75]$.

The lack of differences for the labile organic substances among the study sites in subsurface horizons might be assigned due to the superficial distribution of root chestnut trees [76,77]. Because the labile organic substances are a source of energy and nutrients readily accessible for soil microbial communities [78,79], the higher WSOC content in the A horizon of $\mathrm{NCF}_{\mathrm{L}}$ can also explain the greatest amount of microbial biomass (Cmic and Nmic). Despite the higher microbial biomass in A horizon of $\mathrm{NCF}_{\mathrm{L}}$, the microbial respiration did not show differences among the stands for the A horizon. Conversely, it was interesting to observe how the A horizon of $\mathrm{NCF}_{\mathrm{L}}$ showed the lowest values of RCUM:Cmic and SBR:Cmic, which would indicate how $\mathrm{NCF}_{\mathrm{L}}$ management favored a more efficient microbial growth $[80,81]$. Furthermore, $\mathrm{NCF}_{\mathrm{L}}$ also showed a better use efficiency of the heterotrophic microbes of the easily available substrates, as highlighted by the lowest values of RCUM:WSOC ratio [82]. Hence, the lowest RCUM:Cmic, SBR:Cmic and RCUM:WSOC ratios together with the highest $\mathrm{Cmic}$ content would suggest that the soil microbes, harbored in $\mathrm{A}$ horizon of $\mathrm{NCF}_{\mathrm{L}}$, require less energy for their maintenance and address the assimilated $C$ to their growth. In addition, the higher Cmic:TOC ratio in $\mathrm{NCF}_{\mathrm{L}}$ compared to the other managements indicates a larger $\mathrm{C}$ immobilization in the microbial biomass [83]. Although for the most surface mineral horizon $\mathrm{NCF}_{\mathrm{L}}$ showed the best microbial $\mathrm{C}$ use efficiency, in the deepest soil horizons (B and $\mathrm{BC}$ horizons) both chestnut stands for nut production showed faster $\mathrm{C}$ turnover rates, indicating the development of a microbial community with a high catabolic activity and turnover [84].

Although the sweet chestnut trees generally grow in environments very similar to that investigated in the present work, we are aware that our results need to be interpreted with caution because our study took into account an area with specific pedo-climatic conditions. Therefore, in order to obtain a clearer picture about the effects of the studied managements on soil properties, similar investigations in other pedo-climatic environments are needed.

\section{Conclusions}

This study provides novel information on the effects of different recovery strategies on some soil chemical and biological soil properties in a representative abandoned chestnut forest located in a mountainous area. In particular, the present paper pointed out how the recovery of an abandoned chestnut forest to a pure chestnut one for agricultural purposes (timber and nut production) did not negatively affect the indicators of soil quality (TOC, WSOC, Cmic, microbial activity, soil fertility). Therefore, view of the re-evaluation of mountainous areas, the establishment of chestnut forests could strike the right balance due to the environmental and socio-economic services provided by chestnut forests. Among the tested pure chestnut stand managements, the forest used for nut production and with a plant spacing of 98 plants ha ${ }^{-1} \mathrm{~m}$ seems to be the best one, at least from the biological point of view. In fact, $\mathrm{NCF}_{\mathrm{L}}$ showed the lowest energy costs for metabolic maintenance and resource acquisition by soil microbial population. However, in the deeper soil horizons, both chestnut forests for nut production have shown a microbial community characterized by a low $\mathrm{C}$ use efficiency. Overall, our findings highlight that an ecosystem like our studied pure chestnut forests should be promoted in order to synergistically combine their yields and environmentally beneficial attributes within a landscape unit.

Supplementary Materials: The following are available online at http://www.mdpi.com/1999-4907/11/8/786/s1, Table S1: Mean \pm standard error of calcium $(\mathrm{Ca})$, magnesium $(\mathrm{Mg})$, potassium $(\mathrm{K})$, sodium $(\mathrm{Na})$, phosphorus $(\mathrm{P})$ and sulfur (S) contents in Oi horizon of a chestnut forest for nut production with a tree density of 98 plants ha $^{-1}$ 
$\left(\mathrm{NCF}_{\mathrm{L}}\right)$, a chestnut forest for wood production with a tree density of 151 plants ha ${ }^{-1}$ (WCF), an abandoned chestnut forest $(\mathrm{ACF})$ and a chestnut forest for nut production with a tree density of 120 plants ha ${ }^{-1}\left(\mathrm{NCF}_{\mathrm{H}}\right)$.

Author Contributions: Conceptualization, M.D.F. and L.V.A.; formal analysis, M.D.F.; investigation, M.D.F., G.F. and G.V.; writing —original draft preparation, M.D.F., G.F. and G.V.; writing—review and editing, M.D.F., G.F. and L.V.A.; visualization, M.D.F.; supervision, L.V.A.; project administration, L.V.A.; funding acquisition, L.V.A. All authors have read and agreed to the published version of the manuscript.

Funding: This work was partially funded by the "Accademia Nazionale di Agricoltura" for the project: "Fertility characterization in the chestnut: the nutrients stock $(\mathrm{C}, \mathrm{N}$ and $\mathrm{P})$ and recycling of macroelements $(\mathrm{Ca}, \mathrm{Mg}$ and $\mathrm{K})$.

Conflicts of Interest: The authors declare no conflict of interest.

\section{References}

1. FAOSTAT. FAO-Food and Agriculture Organization of the United Nations. 2017. Available online: http://www.fao.org/faostat/en/\#data/GF (accessed on 7 March 2020).

2. Elands, B.H.M.; O'Leary, T.N.; Boerwinkel, H.W.J.; Wiersum, K.F. Forests as a mirror of rural conditions; Local views on the role of forests across Europe. For. Policy Econ. 2004, 6, 469-482. [CrossRef]

3. Bünemann, E.K.; Bongiorno, G.; Bai, Z.; Creamer, R.E.; De Deyn, G.; de Goede, R.; Fleskens, L.; Geissen, V.; Kuyper, T.W.; Mäder, P.; et al. Soil quality—A critical review. Soil Biol. Biochem. 2018, 120, 105-125. [CrossRef]

4. Grigal, D.F. Effects of extensive forest management on soil productivity. For. Ecol. Manag. 2000, 138, 167-185. [CrossRef]

5. Ballard, T.M. Impacts of forest management on northern forest soils. For. Ecol. Manag. 2000, 133, 37-42. [CrossRef]

6. Huang, Z.; Clinton, P.W.; Davis, M.R.; Yang, Y. Impacts of plantation forest management on soil organic matter quality. J. Soils Sediments 2011, 11, 1309-1316. [CrossRef]

7. Nave, L.E.; DeLyser, K.; Butler-Leopold, P.R.; Sprague, E.; Daly, J.; Swanston, C.W. Effects of land use and forest management on soil carbon in the ecoregions of Maryland and adjacent eastern United States. For. Ecol. Manag. 2019, 448, 34-47. [CrossRef]

8. Grüneberg, E.; Schöning, I.; Hessenmöller, D.; Schulze, E.D.; Weisser, W.W. Organic layer and clay content control soil organic carbon stocks in density fractions of differently managed German beech forests. For. Ecol. Manag. 2013, 303, 1-10. [CrossRef]

9. Goldmann, K.; Schöning, I.; Buscot, F.; Wubet, T. Forest management type influences diversity and community composition of soil fungi across temperate forest ecosystems. Front. Microbiol. 2015, 6, 1300. [CrossRef]

10. Wic Baena, C.; Andrés-Abellán, M.; Lucas-Borja, M.E.; Martínez-García, E.; García-Morote, F.A.; Rubio, E.; López-Serrano, F.R. Thinning and recovery effects on soil properties in two sites of a Mediterranean forest, in Cuenca Mountain (South-eastern of Spain). For. Ecol. Manag. 2013, 308, 223-230. [CrossRef]

11. Borges, O.; Raimundo, F.; Coutinho, J.; Gonçalves, B.; Oliveira, I.; Martins, A.; Madeira, M. Carbon fractions as indicators of organic matter dynamics in chestnut orchards under different soil management practices. Agrofor. Syst. 2018, 92, 301-310. [CrossRef]

12. Gebauer, T.; Horna, V.; Leuschner, C. Canopy transpiration of pure and mixed forest stands with variable abundance of European beech. J. Hydrol. 2012, 442-443, 2-14. [CrossRef]

13. Knoke, T.; Stimm, B.; Ammer, C.; Moog, M. Mixed forests reconsidered: A forest economics contribution on an ecological concept. For. Ecol. Manag. 2005, 213, 102-116. [CrossRef]

14. Joshi, M.; Bargali, K.; Bargali, S.S. Changes in physico-chemical properties and metabolic activity of soil in poplar plantations replacing natural broad-leaved forests in Kumaun Himalaya. J. Arid Environ. 1997, 35, 161-169. [CrossRef]

15. Yang, Y.; Guo, J.; Chen, G.; Yin, Y.; Gao, R.; Lin, C. Effects of forest conversion on soil labile organic carbon fractions and aggregate stability in subtropical China. Plant Soil 2009, 323, 153-162. [CrossRef]

16. Hizal, A.; Gökbulak, F.; Zengin, M.; Ercan, M.; Karakaş, A.; Tuğrul, D. Effect of vegetation change from native broadleaf forest to coniferous plantation on selected soil properties. Environ. Monit. Assess. 2013, 185, 10249-10256. [CrossRef]

17. Yan, E.R.; Wang, X.H.; Huang, J.J.; Li, G.Y.; Zhou, W. Decline of soil nitrogen mineralization and nitrification during forest conversion of evergreen broad-leaved forest to plantations in the subtropical area of Eastern China. Biogeochemistry 2008, 89, 239-251. [CrossRef] 
18. Haghdoost, N.; Akbarinia, M.; Hosseini, S.M.; Kooch, Y. Conversion of Hyrcanian degraded forests to plantations: Effects on soil C and N stocks. Ann. Biol. Res. 2011, 2, 385-399.

19. Da Silva, D.K.A.; de Oliveira Freitas, N.; de Souza, R.G.; da Silva, F.S.B.; de Araujo, A.S.F.; Maia, L.C. Soil microbial biomass and activity under natural and regenerated forests and conventional sugarcane plantations in Brazil. Geoderma 2012, 189-190, 257-261. [CrossRef]

20. Conedera, M.; Tinner, W.; Krebs, P.; de Rigo, D.; Caudullo, G. Castanea sativa in Europe: Distribution, habitat, usage and threats. In European Atlas of Forest Tree Species; Joint Research Centre: Brussels, Belgium, 2016; pp. 78-79.

21. Conedera, M.; Krebs, P.; Tinner, W.; Pradella, M.; Torriani, D. The cultivation of Castanea sativa (Mill.) in Europe, from its origin to its diffusion on a continental scale. Veg. Hist. Archaeobot. 2004, 13, 161-179. [CrossRef]

22. Poljak, I.; Idžojtić, M.; Šatović, Z.; Ježić, M.; Ćurković-Perica, M.; Simovski, B.; Acevski, J.; Liber, Z. Genetic diversity of the sweet chestnut (Castanea sativa Mill.) in Central Europe and the western part of the Balkan Peninsula and evidence of marron genotype introgression into wild populations. Tree Genet. Genomes 2017, 13, 18. [CrossRef]

23. Manetti, M.C.; Amorini, E.; Becagli, C.; Conedera, M.; Giudici, F. Productive potentiality of chestnut (Castanea sativa Mill.) stands over Europe. For. Snow Landsc. Res. 2001, 76, 471-476.

24. Gehring, E.; Kast, C.; Kilchenmann, V.; Bieri, K.; Gehrig, R.; Pezzatti, G.B.; Conedera, M. Impact of the asian chestnut gall wasp, dryocosmus kuriphilus (hymenoptera, cynipidae), on the chestnut component of honey in the southern swiss alps. J. Econ. Entomol. 2018, 111, 43-52. [CrossRef] [PubMed]

25. Diamandis, S. Management of chestnut blight in Greece using hypovirulence and silvicultural interventions. Forests 2018, 9, 492. [CrossRef]

26. Zlatanov, T.; Schleppi, P.; Velichkov, I.; Hinkov, G.; Georgieva, M.; Eggertsson, O.; Zlatanova, M.; Vacik, H. Structural diversity of abandoned chestnut (Castanea sativa Mill.) dominated forests: Implications for forest management. For. Ecol. Manag. 2013, 291, 326-335. [CrossRef]

27. Pezzi, G.; Maresi, G.; Conedera, M.; Ferrari, C. Woody species composition of chestnut stands in the Northern Apennines: The result of 200 years of changes in land use. Landsc. Ecol. 2011, 26, 1463-1476. [CrossRef]

28. Gondard, H.; Romane, F.; Grandjanny, M.; Li, J.; Aronson, J. Plant species diversity changes in abandoned chestnut (Castanea sativa) groves in southern France. Biodivers. Conserv. 2001, 10, 189-207. [CrossRef]

29. Conedera, M.; Stanga, P.; Oester, B.; Bachmann, P. Different post-culture dynamics in abandoned chestnut orchards and coppices. For. Snow Landsc. Res. 2001, 76.3, 487-492.

30. Pettenella, D. Marketing perspectives and instruments for chestnut products and services. For. Snow Landsc. Res. 2001, 76, 511-517.

31. Karaseva, V.; Bergeret, A.; Lacoste, C.; Ferry, L.; Fulcrand, H. Influence of extraction conditions on chemical composition and thermal properties of chestnut wood extracts as tannin feedstock. ACS Sustain. Chem. Eng. 2019, 7, 17047-17054. [CrossRef]

32. Nocetti, M.; Brunetti, M.; Bacher, M. Efficiency of the machine grading of chestnut structural timber: Prediction of strength classes by dry and wet measurements. Mater. Struct. Constr. 2016, 49, 4439-4450. [CrossRef]

33. Vannini, A.; Vettraino, A.M. Ink disease in chestnuts: Impact on the European chestnut. For. Snow Landsc. Res. 2001, 76, 345-350.

34. Vittori Antisari, L.; Falsone, G.; Carbone, S.; Vianello, G. Short-term effects of forest recovery on soil carbon and nutrient availability in an experimental chestnut stand. Biol. Fertil. Soils 2013, 49, 165-173. [CrossRef]

35. FAO. World Reference base for Soil Resources 2014. In International Soil Classification System for Naming Soils and Creating Legends for Soil Maps; FAO: Rome, Italy, 2014.

36. Schoeneberger, P.J.; Wysocki, D.A.; Benham, E.C. Soil Survey Staff Field Book for Describing and Sampling Soils, Version 3.0. In Natural Resources Conservation Service; National Soil Survey Center: Lincoln, NE, USA, 2012.

37. Gee, G.W.; Bauder, J.W. Methods of Soil Analysis: Part 1-Physical and Mineralogical Methods; SSSA Book Series; Soil Science Society of America: Madison, WI, USA; American Society of Agronomy: Madison, WI, USA, 1986; Volume sssabookse, ISBN 978-0-89118-864-3. 
38. Vittori Antisari, L.; Bianchini, G.; Dinelli, E.; Falsone, G.; Gardini, A.; Simoni, A.; Tassinari, R.; Vianello, G. Critical evaluation of an intercalibration project focused on the definition of new multi-element soil reference materials (AMS-MO1 and AMS-ML1). EQA-Int. J. Environ. Qual. 2014, 15, 41-64.

39. Kuo, S. Phoshorus. In Methods of Soil Analysis, Part 3. Chemical Methods; Sparks, D.L., Page, A.L., Helmke, P.A., Loeppert, R.H., Soltanpour, P.N., Tabatabai, M.A., Johnston, C.T., Sumner, M.E., Eds.; SSSA Book Series; ACSESS: Madison, WI, USA, 1996; pp. 869-919.

40. Olsen, S.R.; Cole, C.V.; Watandbe, F.; Dean, L. Estimation of available phosphorus in soil by extraction with sodium bicarbonate. J. Chem. Inf. Model. 1954, 53, 1689-1699.

41. Orsini, L.; Rémy, J. Utilisation du chlorure de cobaltihexamine pour la détermination simultanée de la capacité d'échange et des bases échangeables des sols. Bull. l'Assocation Française d'Etude du Sol. 1976, 4, 269-279.

42. Ciesielski, H.; Sterckeman, T. Determination of cation exchange capacity and exchangeable cations in soils by means of cobalt hexamine trichloride. Effects of experimental conditions. Agronomie 1997, 17, 1-7. [CrossRef]

43. Brookes, P.C.; Landman, A.; Pruden, G.; Jenkinson, D.S. Chloroform fumigation and the release of soil nitrogen: A rapid direct extraction method to measure microbial biomass nitrogen in soil. Soil Biol. Biochem. 1985, 17, 837-842. [CrossRef]

44. Vance, E.D.; Brookes, P.C.; Jenkinson, D.S. An extraction method for measuring soil microbial biomass C. Soil Biol. Biochem. 1987, 19, 703-707. [CrossRef]

45. Chantigny, M.; Angers, D.; Kaiser, K.; Kalbitz, K. Extraction and Characterization of Dissolved Organic Matter. In Soil Sampling and Methods of Analysis, 2nd ed.; Carter, M.R., Gregorich, E.G., Eds.; CRC Press: Boca Raton, FL, USA; Taylor \& Francis: Boca Raton, FL, USA, 2007.

46. Antisari, L.V.; Falsone, G.; Carbone, S.; Marinari, S.; Vianello, G. Douglas-fir reforestation in North Apennine (Italy): Performance on soil carbon sequestration, nutrients stock and microbial activity. Appl. Soil Ecol. 2015, 86, 82-90. [CrossRef]

47. Caravaca, F.; Masciandaro, G.; Ceccanti, B. Land use in relation to soil chemical and biochemical properties in a semiarid Mediterranean environment. Soil Tillage Res. 2002, 68, 23-30. [CrossRef]

48. Marinari, S.; Mancinelli, R.; Campiglia, E.; Grego, S. Chemical and biological indicators of soil quality in organic and conventional farming systems in Central Italy. Ecol. Indic. 2006, 6, 701-711. [CrossRef]

49. Bending, G.D.; Turner, M.K.; Rayns, F.; Marx, M.C.; Wood, M. Microbial and biochemical soil quality indicators and their potential for differentiating areas under contrasting agricultural management regimes. Soil Biol. Biochem. 2004, 36, 1785-1792. [CrossRef]

50. Salazar, S.; Sánchez, L.E.; Alvarez, J.; Valverde, A.; Galindo, P.; Igual, J.M.; Peix, A.; Santa-Regina, I. Correlation among soil enzyme activities under different forest system management practices. Ecol. Eng. 2011, 37, 1123-1131. [CrossRef]

51. Mendham, D.S.; Sankaran, K.V.; O'Connell, A.M.; Grove, T.S. Eucalyptus globulus harvest residue management effects on soil carbon and microbial biomass at 1 and 5 years after plantation establishment. Soil Biol. Biochem. 2002, 34, 1903-1912. [CrossRef]

52. Obalum, S.E.; Chibuike, G.U.; Peth, S.; Ouyang, Y. Soil organic matter as sole indicator of soil degradation. Environ. Monit. Assess. 2017, 189, 176. [CrossRef]

53. Frouz, J.; Pižl, V.; Cienciala, E.; Kalčík, J. Carbon storage in post-mining forest soil, the role of tree biomass and soil bioturbation. Biogeochemistry 2009, 94, 111-121. [CrossRef]

54. Bolat, I. The effect of thinning on microbial biomass $\mathrm{C}, \mathrm{N}$ and basal respiration in black pine forest soils in Mudurnu, Turkey. Eur. J. For. Res. 2014, 133, 131-139. [CrossRef]

55. Schulp, C.J.E.; Nabuurs, G.J.; Verburg, P.H.; de Waal, R.W. Effect of tree species on carbon stocks in forest floor and mineral soil and implications for soil carbon inventories. For. Ecol. Manag. 2008, 256, 482-490. [CrossRef]

56. Díaz-Pinés, E.; Rubio, A.; Van Miegroet, H.; Montes, F.; Benito, M. Does tree species composition control soil organic carbon pools in Mediterranean mountain forests? For. Ecol. Manag. 2011, 262, 1895-1904. [CrossRef]

57. Hättenschwiler, S. Effects of tree species diversity on litter quality and decomposition. In Forest Diversity and Function; Springer: Heidelberg, Germany, 2005; pp. 149-164.

58. Yost, J.L.; Hartemink, A.E. Soil organic carbon in sandy soils: A review. Adv. Agron. 2019, 158, $217-310$.

59. Campos, C.A.; Suárez, M.G.; Laborde, J. Analyzing vegetation cover-induced organic matter mineralization dynamics in sandy soils from tropical dry coastal ecosystems. Catena 2020, 185, 104264. [CrossRef] 
60. Ganuza, A.; Almendros, G. Organic carbon storage in soils of the Basque Country (Spain): The effect of climate, vegetation type and edaphic variables. Biol. Fertil. Soils 2003, 37, 154-162. [CrossRef]

61. Michopoulos, P.; Kaoukis, K.; Karetsos, G.; Grigoratos, T.; Samara, C. Nutrients in litterfall, forest floor and mineral soils in two adjacent forest ecosystems in Greece. J. For. Res. 2020, 31, 291-301. [CrossRef]

62. Azeez, J.O. Recycling organic waste in managed tropical forest ecosystems: Effects of arboreal litter types on soil chemical properties in Abeokuta, southwestern Nigeria. J. For. Res. 2019, 30, 1903-1911. [CrossRef]

63. Cremer, M.; Prietzel, J. Soil acidity and exchangeable base cation stocks under pure and mixed stands of European beech, Douglas fir and Norway spruce. Plant Soil 2017, 415, 393-405. [CrossRef]

64. Borrelli, P.; Panagos, P.; Märker, M.; Modugno, S.; Schütt, B. Assessment of the impacts of clear-cutting on soil loss by water erosion in Italian forests: First comprehensive monitoring and modelling approach. Catena 2017, 149, 770-781. [CrossRef]

65. Zhang, B.; Yang, Y.S.; Zepp, H. Effect of vegetation restoration on soil and water erosion and nutrient losses of a severely eroded clayey Plinthudult in southeastern China. Catena 2004, 57, 77-90. [CrossRef]

66. Desie, E.; Vancampenhout, K.; Nyssen, B.; van den Berg, L.; Weijters, M.; van Duinen, G.J.; den Ouden, J.; Van Meerbeek, K.; Muys, B. Litter quality and the law of the most limiting: Opportunities for restoring nutrient cycles in acidified forest soils. Sci. Total Environ. 2020, 699, 134383. [CrossRef]

67. Hancock, G.R.; Kunkel, V.; Wells, T.; Martinez, C. Soil organic carbon and soil erosion-Understanding change at the large catchment scale. Geoderma 2019, 343, 60-71. [CrossRef]

68. Rizinjirabake, F.; Tenenbaum, D.E.; Pilesjö, P. Sources of soil dissolved organic carbon in a mixed agricultural and forested watershed in Rwanda. Catena 2019, 181. [CrossRef]

69. Belair, E.D.; Saunders, M.R.; Bailey, B.G. Four-year response of underplanted American chestnut (Castanea dentata) and three competitors to midstory removal, root trenching, and weeding treatments in an oak-hickory forest. For. Ecol. Manag. 2014, 329, 21-29. [CrossRef]

70. Brown, C.E.; Bailey, B.G.; Saunders, M.R.; Jacobs, D.F. Effects of root competition on development of chestnut and oak regeneration following midstory removal. Forestry 2014, 87, 562-570. [CrossRef]

71. Ahmed, A.K.M.; Fu, Z.; Ding, C.; Jiang, L.; Han, X.; Yang, A.; Ma, Y.; Zhao, X. Growth and wood properties of a 38-year-old Populus simonii $\times$ P. nigra plantation established with different densities in semi-arid areas of northeastern China. J. For. Res. 2020, 31, 497-506. [CrossRef]

72. Ramalho, F.M.G.; Pimenta, E.M.; Goulart, C.P.; De Almeida, M.N.F.; Vidaurre, G.B.; Hein, P.R.G. Effect of stand density on longitudinal variation of wood and bark growth in fast-growing eucalyptus plantations. IForest 2019, 12, 527-532. [CrossRef]

73. Ni, J.; Ng, C.W.W.; Gao, Y. Modelling root growth and soil suction due to plant competition. J. Theor. Biol. 2020, 484, 110019. [CrossRef]

74. Agnelli, A.; Massaccesi, L.; De Feudis, M.; Cocco, S.; Courchesne, F.; Corti, G. Holm oak (Quercus ilex L.) rhizosphere affects limestone-derived soil under a multi-centennial forest. Plant Soil 2016, 400, 297-314. [CrossRef]

75. Angst, G.; Kögel-Knabner, I.; Kirfel, K.; Hertel, D.; Mueller, C.W. Spatial distribution and chemical composition of soil organic matter fractions in rhizosphere and non-rhizosphere soil under European beech (Fagus sylvatica L.). Geoderma 2016, 264, 179-187. [CrossRef]

76. Frey, B.; Hagedorn, F.; Giudici, F. Effect of girdling on soil respiration and root composition in a sweet chestnut forest. For. Ecol. Manag. 2006, 225, 271-277. [CrossRef]

77. Dazio, E.; Conedera, M.; Schwarz, M. Impact of different chestnut coppice managements on root reinforcement and shallow landslide susceptibility. For. Ecol. Manag. 2018, 417, 63-76. [CrossRef]

78. Gmach, M.R.; Cherubin, M.R.; Kaiser, K.; Cerri, C.E.P. Processes that influence dissolved organic matter in the soil: A review. Sci. Agric. 2020, 77. [CrossRef]

79. McDowell, W.H.; Zsolnay, A.; Aitkenhead-Peterson, J.A.; Gregorich, E.G.; Jones, D.L.; Jödemann, D.; Kalbitz, K.; Marschner, B.; Schwesig, D. A comparison of methods to determine the biodegradable dissolved organic carbon from different terrestrial sources. Soil Biol. Biochem. 2006, 38, 1933-1942. [CrossRef]

80. Anderson, T.H.; Domsch, K.H. Soil microbial biomass: The eco-physiological approach. Soil Biol. Biochem. 2010, 42, 2039-2043. [CrossRef]

81. Culumber, C.M.; Reeve, J.R.; Black, B.L.; Ransom, C.V.; Alston, D.G. Organic orchard floor management impact on soil quality indicators: Nutrient fluxes, microbial biomass and activity. Nutr. Cycl. Agroecosyst. 2019, 115, 101-115. [CrossRef] 
82. Massaccesi, L.; Benucci, G.M.N.; Gigliotti, G.; Cocco, S.; Corti, G.; Agnelli, A. Rhizosphere effect of three plant species of environment under periglacial conditions (Majella Massif, central Italy). Soil Biol. Biochem. 2015, 89, 184-195. [CrossRef]

83. Bargali, K.; Manral, V.; Padalia, K.; Bargali, S.S.; Upadhyay, V.P. Effect of vegetation type and season on microbial biomass carbon in Central Himalayan forest soils, India. Catena 2018, 171, 125-135. [CrossRef]

84. Raiesi, F.; Beheshti, A. Microbiological indicators of soil quality and degradation following conversion of native forests to continuous croplands. Ecol. Indic. 2015, 50, 173-185. [CrossRef]

(C) 2020 by the authors. Licensee MDPI, Basel, Switzerland. This article is an open access article distributed under the terms and conditions of the Creative Commons Attribution (CC BY) license (http://creativecommons.org/licenses/by/4.0/). 